\title{
Adsorption Capacity of Activated Charcoal Made of Rice Husk on Cd(II) Metal Ions
}

\author{
*Eka Widyasari, Supriadi \& Irwan Said
}

Pendidikan Kimia/FKIP - Universitas Tadulako, Palu - Indonesia 94119

Received 22 December 2020, Revised 27 January 2021, Accepted 04 November 2021

doi: $10.22487 / j 24775185.2021 . v 10 . i 4 . p p 213-217$

\begin{abstract}
Rice husk is one of the by-products of the rice milling process that can be used as activated charcoal to adsorb metal ions. This study aimed to determine the optimum $p H$ and adsorption capacity of Cd(II) ions by activated charcoal made of rice husk using the Atomic Absorption Spectrophotometry (AAS) method. The optimum pH adsorption of activated charcoal was determined by varying the $p H$ of 2, 3, 4, 5, 6, 7, and 8. Based on the analysis results of the optimum $\mathrm{pH}$ for metal adsorption, $\mathrm{pH} 7 \mathrm{with}$ percent absorbed metal $99.94 \%$, while adsorption of $C d(I I)$ ions using activated charcoal was carried out with several variations of concentration to study adsorption isotherm. The adsorption isotherm model of activated charcoal adsorption followed the Langmuir isotherm model. This analysis obtained that the maximum adsorption capacity $\left(q_{\max }\right)$ of Cd(II) ions was $2.068 \mathrm{mg} \mathrm{Cd} / \mathrm{g}$.
\end{abstract}

Keywords: Adsorption, rice husk, $\mathrm{Cd}(\mathrm{II})$ ion, $\mathrm{pH}$ variation

\section{Introduction}

The development of the industrial sector in Indonesia is currently relatively rapid. This is indicated by the increasing number of industries that produce various types of human needs, such as the paint, enamel, and plastic industries. The development of industry has a positive impact and can also provide by-products produced as waste. One of these wastes is heavy metal waste (Nurhasni et al., 2010).

Heavy metals are metal elements with high molecular weight and are pollutants that significantly impact the health of living things. In low levels, heavy metals are generally toxic to plants and animals, including humans (Syauqiah et al., 2011). One example of a hazardous heavy metal is cadmium $(\mathrm{Cd})$, where this metal is one of the metals grouped into non-essential heavy metals, meaning that its usefulness in the body is not yet known; this is due to the biotransformation process and bioaccumulation of cadmium in living organisms. The negative impact of $\mathrm{Cd}$ metal in the human body is that it can inhibit the work of the lungs and even cause lung cancer, nausea, vomiting, diarrhea, cramps, anemia, kidney, and liver damage (Suhud et al., 2012).

Heavy metal Cd contained in marine vehicle fuels can trigger high levels of $\mathrm{Cd}$ heavy metal in seawater, Mamboro sea waters. Where the sea waters play an important role in supporting the life needs of some people, the most common is in the form of fish needs and the existence of seaweed cultivation which can increase income for some people, especially anglers. Meanwhile, in the coastal area of Mamboro, there are types of companies that obtain raw materials by using sea transportation. The activities are loading and unloading the raw materials to be used and replacing fuel oil with ships that lean to trigger seawater pollution (Rahmadani et al., 2015).

Pollution caused by $\mathrm{Cd}$ metal is hazardous to the environment and, in particular, can impact humans, which is non-biodegradable, toxic (poisonous), and can experience accumulation of chemical substances in the food chain (Anis \& Gusrizal, 2006). Several methods to remove heavy metals from waste include adsorption, ion exchange, and membrane separation. Among these methods, adsorption is the most commonly used method because it has a more straightforward concept, is more economical, does not cause toxic side effects, and can remove inorganic and organic materials (Nurhasni et al., 2014).

Adsorption is the process of adsorbate accumulation on the adsorbent surface caused by the attractive forces between the adsorbate molecules and the adsorbent surface. The interactions that occur in the adsorbate molecule with the surface may be followed by more than one interaction, depending on the chemical structure of each component (Nurhasni et al., 2014).

One type of plant that can be used to adsorb heavy metals is the rice husk. Rice husks have low nutritional value, are resistant to weathering, have high charcoal content, are abrasive, resemble wood

${ }^{*}$ Correspondence:

Eka Widyasari

e-mail: ekawidyasari074@gmail.com

(c) 2021 the Author(s) retain the copyright of this article. This article is published under the terms of the Creative Commons Attribution License 4.0, which permits unrestricted non-commercial use, distribution, and reproduction in any medium, provided the original work is properly cited. 
content, and have a high enough carbon content, with a high enough carbon content indicating that rice husks can be used as raw material for making charcoal active (Riapanitra et al., 2004). Previous research on activated charcoal from rice husks has been carried out (Widayanti et al., 2012).

Rice husks can be used as adsorbents because, apart from being a porous material, it also has active groups, namely O-Si-O and $\mathrm{Si}-\mathrm{OH}$ (Nurhasni et al., 2014). The silica ( $\mathrm{SiO} 2)$ content in rice husk charcoal reaches $80-90 \%$. When the rice husks burn, about $20 \%$ of the rice husks turn into charcoal. According to Mahvi et al. (2004), rice husk charcoal has more than $95 \%$ by weight of silica with high porosity and wide surface area because it is a framework and cellular structure.

Burning rice husks at temperatures $<500{ }^{\circ} \mathrm{C}$ can turn into charcoal, a source of silica in amorphous form. This combustion can produce \pm $20 \%$ charcoal from the husk weight that is burned and contains silica $(\mathrm{SiO})$ as the main component of about $96.6 \%$. By the properties of silicate compounds, temperature changes can result in changes in the shape of the silicate compounds. To get this amorphous form, combustion is carried out at temperatures $<500{ }^{\circ} \mathrm{C}$ for \pm 5 hours (Hadiwidodo, 2008).

The purpose of this paper is to describe the adsorption capacity of rice husk-activated charcoal against $\mathrm{Cd}(\mathrm{II})$ metal ions by determining the effect of $\mathrm{pH}$ and adsorption capacity of activated rice husk charcoal in the absorption of $\mathrm{Cd}(\mathrm{II})$ metal ions.

\section{Methods}

The tools used are Atomic Absorption Spectrophotometer (AAS), beaker, measuring cup, measuring flask, Erlenmeyer, spatula, stirring rod, dropper, funnel, $\mathrm{pH}$ meter, shaker, blender, spray bottle, digital balance, furnace, porcelain cup, and a 70 mesh sieve.

The materials used were rice husks, sample solution of $\mathrm{Cd}\left(\mathrm{NO}_{3}\right)_{2} .4 \mathrm{H}_{2} \mathrm{O}\left(\right.$ Merck), $\mathrm{HNO}_{3} 1 \%$ (Merck), $\mathrm{NaOH} 1 \mathrm{M}$ (Merck), $\mathrm{NaCl}$ 20\% (Merck), distilled water, aluminum foil, and Whatman filter paper. 42.

\section{Sample preparation}

The rice husks are washed with water until clean and dry in the sun to dry. Then it was charred at $400{ }^{\circ} \mathrm{C}$ for 1 hour. Then crushed and sieved using a 70 mesh sieve. Furthermore, the charcoal obtained is activated with $20 \% \mathrm{NaCl}$ solution and allowed to stand for 24 hours, then filtered and washed with distilled water until neutral, then heated in a kiln at $300^{\circ} \mathrm{C}$ for 1 hour. The activated charcoal produced is stored in the heavy metal adsorption process (Widayanti et al., 2012).

\section{Testing characteristics of activated charcoal}

Activated charcoal is carefully weighed 1 gram in a known-weight porcelain dish, then dried in an oven at a temperature of $105^{\circ} \mathrm{C}$ for about 3 hours. After that, it is cooled in a desiccator and weighed.
The same treatment was repeated until a constant weight was obtained (CEFIC, 1986). The procedure for testing the ash content is that activated charcoal is weighed carefully as much as 1 gram in a known weight plate. Then in the furnace at a temperature of $600{ }^{\circ} \mathrm{C}$ for 1 hour. After that, it is cooled in a desiccator and weighed. The same treatment is repeated until a fixed weight is obtained (CEFIC, 1986).

\section{Determination of the optimum ph of Cd(II) ion adsorption by rice husk}

A total of $25 \mathrm{~mL}$ of $10 \mathrm{ppm} \mathrm{Cd}$ (II) ion solution was put into Erlenmeyer then the $\mathrm{pH}$ varied in the range of $2,3,4,5,6,7$, and 8 . Then 0.5 grams of rice husk charcoal adsorbent was added and covered with aluminum. The foil is then in the shaker for 1 hour. After that, it was filtered with Whatman 42 filter paper, the absorption of the filtrate obtained was measured using Atomic Absorption Spectrophotometry (AAS) (Nurhasni et al., 2014).

\section{Determination of $C d(I I)$ ion adsorption capacity by rice husk}

A total of $25 \mathrm{~mL}$ of $\mathrm{Cd}$ (II) ion solution with a concentration of $5,10,15$, and $20 \mathrm{ppm}$ at optimum $\mathrm{pH}$ was put into Erlenmeyer. Then 0.5 grams of rice husk charcoal adsorbent were added, covered with aluminum foil, and then shaken for 1 hour. After that, it was filtered with Whatman 42 filter paper, the absorption of the filtrate obtained was measured using Atomic Absorption Spectrophotometry (AAS).

\section{Results and Discussion}

\section{Characteristics of activated charcoal}

This research is one way to reduce environmental pollution by utilizing rice husks which are considered waste by the community, by turning them into charcoal as heavy metal adsorbents to reduce levels of $\mathrm{Cd}$ metal in the aquatic environment. The resulting rice husk charcoal is activated with $20 \% \mathrm{NaCl}$ solution. Activation of charcoal is done chemically with $20 \%$ $\mathrm{NaCl}$, which can remove carbonized hydrocarbons and function as a dehydrating agent that eliminates water in the pores of activated charcoal. The charcoal is then washed with distilled water until it reaches a neutral $\mathrm{pH}$. This aims to remove impurities from chemical activation. Furthermore, the calcination stage is carried out at $300{ }^{\circ} \mathrm{C}$ for 1 hour; calcination at high temperatures will expand the pore surface of activated charcoal. This happens because the activation at high temperatures will push the impurities and the carbonized hydrocarbons out of the pores of activated charcoal, which causes an increase in the pore volume of activated charcoal (Widayanti et al., 2012).

\section{Water content}

One of the requirements of activated charcoal is water content. Determination of water content aims to determine the hygroscopic properties of 
activated rice husk charcoal (Wijayanti, 2009). According to Herlandien (2013), the high water content in activated charcoal will reduce liquids and gases' capacity and adsorption power. The average water content of activated charcoal obtained is $3.41 \%$. Based on the results obtained, the water content of activated rice husk charcoal is relatively low and by the Indonesian National Standard (SNI), where the requirement for a good water content is a maximum of $15 \%$ (Pujiarti \& Sutapa, 2005).

\section{Ash content}

Another parameter for activated charcoal requirements is the ash content. The aim is to determine the amount of activated charcoal ash content of rice husks. The activated charcoal ash content is determined to decide on the oxide content in activated charcoal (Pujiarti \& Sutapa, 2005). The presence of excess ash can cause clogging of the pores in activated rice husk charcoal so that the surface area of activated rice husk charcoal decreases. The ash content obtained was $10.34 \%$. The results obtained indicate that the ash content contained in inactivated rice husk charcoal is relatively low so that it can adsorb gas and solution and is by the Indonesian National Standard (SNI), where the requirement for a good ash content is a maximum of 10\% (Lotuponu et al., 2011).

Determination of the concentration of Cd(II) metal in an equilibrium state was measured using Atomic Absorption Spectrophotometry (AAS) with air-acetylene flame, the amount of Cd(II) metal absorbed (qe) by activated rice husk charcoal was the difference in the concentration of $\mathrm{Cd}(\mathrm{II})$ metal initially $(\mathrm{Ci})$ with the metal concentration of $\mathrm{Cd}(\mathrm{II})$ at equilibrium (Ceq). The optimum $\mathrm{pH}$ is needed to obtain $\mathrm{Cd}(\mathrm{II})$ metal uptake, which is also a variable in this study.

\section{$p H$ variation to the $C d(I I)$ ion adsorption by rice husk activated charcoal}

The degree of acidity $(\mathrm{pH})$ is a factor that significantly influences the adsorption process of metal ions in solution because the presence of $\mathrm{H}+$ ions in solution will compete with cations to bind to the active site. In addition, $\mathrm{pH}$ will also affect the ion species present to interact with the active adsorbent site (Lestari et al., 2003).

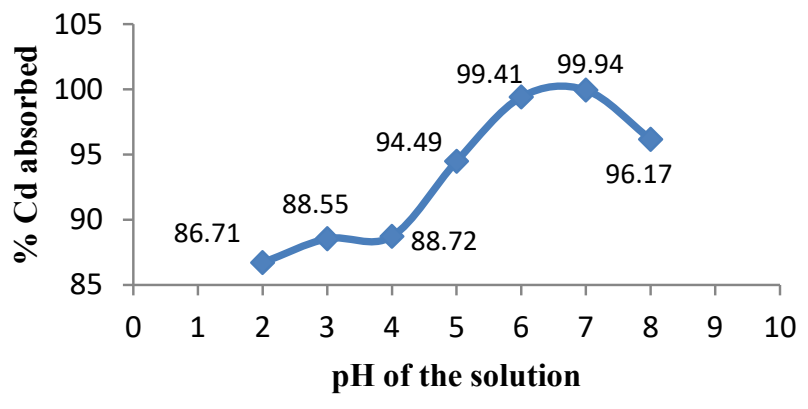

Figure 1. Relationship between the $\mathrm{pH}$ of the solution to the percent adsorbed $\mathrm{Cd}$

Figure 1 shows that the adsorption power increases with increasing $\mathrm{pH}$. The optimum $\mathrm{pH}$ is determined to determine the $\mathrm{pH}$ of the interaction where the adsorbent absorbs the adsorbate maximally. Adsorption of $\mathrm{Cd}(\mathrm{II})$ ions is influenced by the $\mathrm{pH}$ of the solution, where adsorption at $\mathrm{pH}$ 2 with an absorption percentage of $86.71 \%$ increases at $\mathrm{pH} 3.4,5,6$, and 7 , with the respective percentages being $88.55,88,72,94.49,99.41$, and $99.94 \%$. Still, at pH 8, the absorption percentage decreased, namely $96.17 \%$. This shows that the absorption in $\mathrm{pH} 2$ conditions occurs relatively low, namely $86.71 \%$, while at $\mathrm{pH} 3-7$, it increases with an average value of 88.55 to $99.94 \%$.

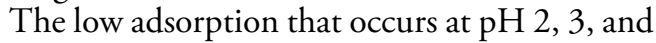
4 is due to intense $\mathrm{pH}$ competition between $\mathrm{H}^{+}$and $\mathrm{Cd}^{2+}$ to interact with functional groups on the surface of activated rice husk charcoal and also at low $\mathrm{pH}$ functional groups on the surface of activated rice husk charcoal—surrounded by $\mathrm{H}^{+}$ions to prevent the interaction between cadmium ions and functional groups on the surface of activated rice husk charcoal (Tumin, 2008). In addition, the adsorbent surface is positively charged, which will cause repulsion against $\mathrm{Cd}^{2+}$ ions (Nurhasni et al., 2014).

Increased adsorption at $\mathrm{pH}$ 5-7 and decreased at $\mathrm{pH}$ 8. This indicates that in the $\mathrm{pH}$ range of 8 , $\mathrm{Cd}(\mathrm{II})$ ions will begin to form a precipitate causing a decrease in adsorption of $\mathrm{Cd}(\mathrm{II})$ ions by activated rice husk charcoal. This is because there is no more extended competition between $\mathrm{H}+$ and the ionized charcoal surface at this high $\mathrm{pH}$ by releasing $\mathrm{H}^{+}$ions and the char surface becomes negative. The effect of conditions at high $\mathrm{pH}$ causes the formation of the hydroxy species $\mathrm{Cd}(\mathrm{OH})_{2}$, which settles in the solution (Wijaya \& Ulfin, 2015).

The optimum $\mathrm{pH}$ of 7 in this study is by the results obtained by Wijaya \& Ulfin (2015), who used the same metal type but different types of adsorbent, with tamarind seed charcoal as the adsorbent. Based on the description above, it can be 
seen that the optimum adsorption for Cd(II) metal ions occurs at $\mathrm{pH} 7$

\section{Adsorption capacity of $C d(I I)$ ion by activated rice} husk charcoal

The Langmuir and Freundlich isotherm equation determined the maximum adsorption capacity of $\mathrm{Cd}(\mathrm{II})$ ions. The adsorption isotherm is determined by analyzing the linearity of the relationship curve according to the Langmuir Freundlich isotherm equation. The first step in determining the adsorption isotherm is to convert the Langmuir and Freundlich equations into straight-line equations.
According to Oscik \& Cooper (2010), Langmuir adsorption assumed that there is a playful side proportional to the adsorbent area on the adsorbent surface. When the active site is not saturated with adsorbate, the increased adsorbate concentration that is exposed will increase linearly with the amount of adsorbed. Meanwhile, the Freundlich isotherm assumes that the adsorption process on the adsorbent surface is heterogeneous. A $\log$ qe curve against $\log \mathrm{C}_{\mathrm{eq}}$ can be made in determining the Freundlich adsorption pattern that follows the Freundlich isotherm from the adsorption data.

\section{Rice husk activated charcoal adsorption isotherm}

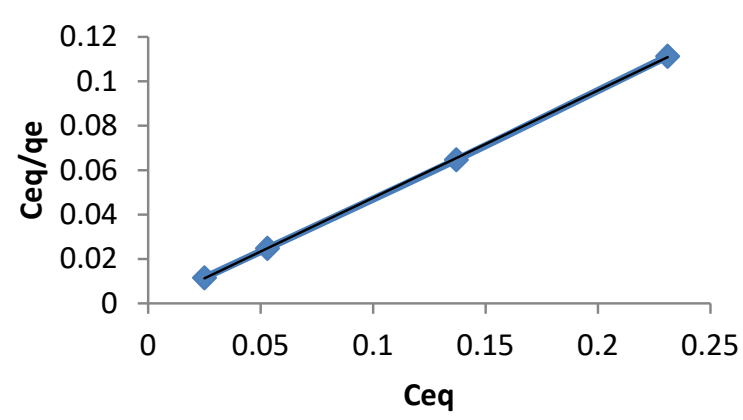

Figure 2 The linearity curve of the Langmuir metal Cd(II) isotherm

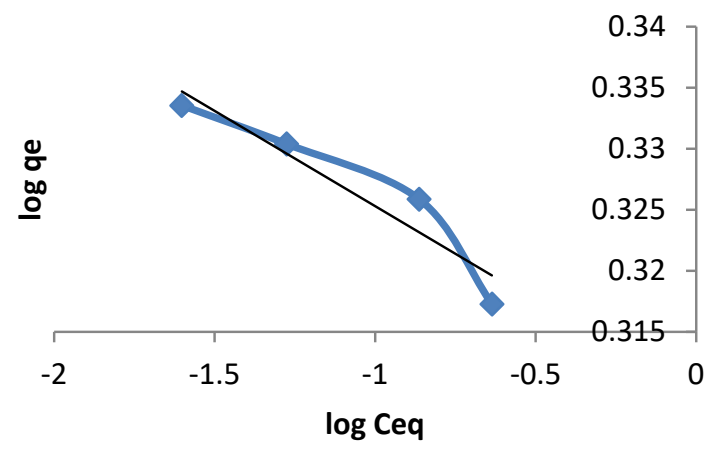

Figure 3 Freundlich curve isotherm of metal Cd(II)

Table 1. Rice husk adsorption isotherm data

\begin{tabular}{cccccccc}
\hline \multirow{2}{*}{ Metal } & $\begin{array}{c}\text { qe ekperimen } \\
(\mathrm{mg} / \mathrm{g})\end{array}$ & $\begin{array}{c}\mathrm{q}_{\max } \\
(\mathrm{mg} / \mathrm{g})\end{array}$ & $\mathrm{K}_{\mathrm{L}}$ & $\mathrm{R}^{2}$ & $\mathrm{n}$ & $\mathrm{K}_{\mathrm{F}}$ & $\mathrm{R}^{2}$ \\
\hline $\mathrm{Cd}$ & 2.156 & 2.068 & 0.999 & 0.999 & -64.103 & 2.040 & 0.01 \\
\hline
\end{tabular}

Based on the data shown in Figures 2 and 3, it can be determined the adsorption pattern of Cd(II) metal ion by activated rice husk charcoal by comparing the linear regression coefficient $\left(\mathrm{R}^{2}\right)$ where the Langmuir adsorption isotherm curve obtained a linear regression coefficient value of 
0.9999 while for the adsorption isotherm Freundlich of 0.901 . Judging from the $\mathrm{R}^{2}$ value, the $\mathrm{Cd}(\mathrm{II})$ metal ion adsorption model by rice husk activated charcoal is more by the Langmuir isotherm than the Freundlich isotherm. This proves that the surface of activated rice husk charcoal has an active side on the homogeneous surface. The absorption affinity $(\mathrm{KL})=0.999$ and the maximum adsorption capacity $\left(\mathrm{q}_{\max }\right)$ of $\mathrm{Cd}(\mathrm{II})$ ion was $2.068 \mathrm{mg} \mathrm{Cd} / \mathrm{g}$. This means that every 1 gram of activated rice husk charcoal can adsorb $2.068 \mathrm{mg}$ of Cd(II) ions.

\section{Conclusions}

The optimum adsorption of $\mathrm{Cd}(\mathrm{II})$ ions by activated rice husk charcoal occurred at $\mathrm{pH} 7$ with a percentage of $\mathrm{Cd}(\mathrm{II})$ ions absorbed by $99.94 \%$, where the adsorption process has increased with increasing $\mathrm{pH}$. The higher the $\mathrm{pH}$, the greater the adsorption power. The maximum adsorption capacity of activated rice husk charcoal to absorb $\mathrm{Cd}(\mathrm{II})$ ions is $2,068 \mathrm{mg} \mathrm{Cd} / \mathrm{g}$ of activated rice husk charcoal.

\section{Acknowledgments}

The author's gratitude goes to the laboratory assistant for Chemistry Education, Teaching and Education Faculty, Tadulako University, and the Health of Palu City, Central Sulawesi, who helped me complete this research.

\section{References}

Anis, S., \& Gusrizal. (2006). Pengaruh pH dan penentuan kapasitas adsorpsi logam berat pada biomassa eceng gondok (Eichhornia crassipes). Jurnal Kimia, 6(1), 56-60.

CEFIC. (1986). Test methods for activated carbon. Diakses 12 Mei 2019, dari https://activatedcarbon.org/index.php/activa ted-carbon/what .

Hadiwidodo, M. (2008). Penggunaan abu sekam padi sebagai adsorben dalam pengolahan air limbah yang mengandung logam $\mathrm{Cu}$. Jurnal Ilmiah Bidang Ilmu Kerekayasaan, 29(1), 5563.

Herlandien, Y. L. (2013). Pemanfaatan arang aktif sebagai adsorben logam berat dalam air lindi di TPA Pakusari Jember. Skripsi Tidak Diterbitkan. Jember: Universitas Jember.

Lestari, S., Eko, S., \& Mudasir. (2004). Studi kemampuan adsorpsi biomassa saccharomyces cerevisiae yang termobilkan pada silika gel terhadap Tembaga(II). Jurnal Sains dan Teknologi, 16(3), 357-371.

Lotuponu, H., Shiddieq, D., Syukur, A., \& Hanudin, E. (2011). Pengaruh biochar dari limbah sagu terhadap pelindian Nitrogen di lahan kering masam. Jurnal Agronomika, 11(2), 130-137.

Mahvi, A. H., Maleki, A., \& Eslami, A. (2004).
Potential of rice husk and rice husk ash for phenol removal in aqueous systems. American Journal of Applied Sciences, 1(4), 321-3226.

Nurhasni, Hendrawati., \& Saniyyah, N. (2010). Penyerapan ion logam $\mathrm{Cd}$ dan $\mathrm{Cr}$ dalam air limbah menggunakan sekam padi. Jurnal Kimia Valensi, 1(6), 311-318.

Nurhasni, Hendrawati., \& Saniyyah, N. (2014). Sekam padi untuk menyerap ion logam tembaga dan timbal dalam air limbah. Jurnal Kimia Valensi, 4(1), 36-44.

Oscik, J., \& Cooper, L. (1982). Adsorption. New York: Ellis Horwood.

Pujiarti, R., \& Sutapa, J. P. G. (2005). Mutu arang aktif dari lmbah kayu mahoni (Swietenia macrophylla King) sebagai bahan penjernih air. Jurnal Ilmu dan Teknologi Kayu Tropis, 3(2), 33-38.

Rahmadani, T., Sabang, S. M., \& Said, I. (2015). Analisis kandungan logam zink ( $\mathrm{Zn})$ dan timbal $(\mathrm{Pb})$ dalam air laut pantai Mamboro Kecamatan Palu Utara. Jurnal Akademika Kimia, 4(4), 197-203.

Riapanitra, A., Setyaningtyas, T., \& Riyani, K. (2006). Penentuan waktu kontak dan $\mathrm{pH}$ optimum penyerapan metilen biru menggunakan abu sekam. Jurnal Ilmiah Kimia, 1(1), 41-44.

Suhud, I., Tiwow, V. M. A. \& Hamzah, B. (2012). Adsorpsi ion kadmium (II) dari larutannya menggunakan biomassa akar dan batang kangkung air (Ipomoea aquatica Forks). Jurnal Akademi Kimia, 1(4), 153-158.

Syauqiah, I, Amalia M., \& Hetty A. K. (2011). Analisis variasi waktu dan kecepatan pengaduk pada proses adsorpsi limbah logam berat dengan arang aktif. Jurnal Info Teknik, 12(1), 11-20.

Tumin., Najua, D., Chuah A. L., Zawani, Z., \& Rahsid, S. A. (2008). Adsorption of copper from aqueous solution by elais guineensis kernel activated carbon. Journal of Engineering Science and Technology, 3(2), 180-189.

Widayanti., Ishak, I., \& La Ode, A. (2012). Studi daya aktivasi arang sekam padi pada proses adsorpsi logam Cd. Jurnal Sainstek, 6(5), 488-494.

Wijaya, V. C., \& Ulfin, I. (2015). Pengaruh pH pada adsorpsi ion $\mathrm{Cd}^{2+}$ dalam larutan menggunakan karbon aktif dari biji trembesi (Samanea Saman). Jurnal Sains dan Seni Institut Teknologi Sepuluh, 4(2), C-86-C-89.

Wijayanti, D. S. (2009). Karakteristik briket arang dari serbuk gergaji dengan penambahan arang cangkang kelapa sawit. Skripsi Tidak Diterbitkan. Medan: Universitas Sumatera Utara. 